\title{
DE TROM MET DE HOOFDEN TE PEDJENG OP BALI
}

\author{
DOOR
}

\section{W. O. J. NIEUWENKAMP.}

(Met 6 Platen, door den schrijver in loco geteekend.)

20 October 1906, in den vroegen morgen, verliet ik te voet de hoofdplaats Gianjar in westelijke richting en stapte vlug voort door de wonderschooue landouwen. De weg voerde tusschen sawahs en nu en dan langs diepe rotsige ravijnen, waarin bruisende bergstroompjes. Ik passeerde de dorpen Běbitra, Tĕgallinggah, Patěmon, Kloesoe en Pauglohan en bereikte in een kleine twee uur het dorp Pedjeng ${ }^{1}$, het doel van mijn wandeling. In dit dorp toch ligt in een beroemden tempel een groote bronzen trom, waarvan het bestaan al ruim twee eeuwen bekend was, doch waarover nog steeds niet anders dan vage berichten bestonden. Ik had mij tot doel gesteld wat meer gegevens aangaaude deze trom te verzamelen en zoo mogelijk haar af te beelden.

De tempel was spoedig gevouden. Binnen gaaude werd ik gevolgd door een menigte inlanders, die, als $\mathrm{kwamen}$ ze uit den grond gerezen, zich plotseling om mij hadden verzameld.

Ook het tentje of tempeltje waarin de trom - zie Plaat I had ik weldra ontdekt; hoog op een steeuen voetstuk was de vlakke ronde kant van de trom door een hekwerk te onderscheiden, maar een trapje om het ongeveer drie meter hooge voetstuk te beklimmen, ontbrak.

Nog overwegende hoe nu te handelen, zag ik bij den ingang van het plein het volk eerbiedig uiteenwijken voor een groep die

1 Op de "Schetskaart van Midden-Bali, Schaal 1: 100.000" (Batavia, Topogr. Inrichting, 1906) ten onrechte „Pĕdjeng” geschreven. Het is Pèdjèng, naar de uitspraak. Trouwens, diezelfde kaart geeft bijna recht Noord daarvan, aan een desa be-W. van Tegal-lalang den naam „Pedjengadji" — n's Konings Pedjeng" dus - met juister spelling. 
vol waardigheid kwam binnenstappen. Ik begreep dat dit of de Tjokorda van Pedjeng met gevolg of priesters of andere hooggeplaatste Baliërs moesten zijn; ik besloot ze niet af te wachten, maar stapte vlug op het tempeltje toe en klom er tegen op, waarbij de uitstekende oruamenten van het steenen onderstuk goed te pas kwamen.

$\mathrm{Na}$ de beide deurtjes te hebben geopend, wrong ik mij door het kleine poortje en sloot de deurtjes weer achter mij dicht. Wat een geluk toch mager te zijn! Een dikke ontdekkingsreiziger zou zich nooit door den uiterst smallen doorgang hebben kunnen wringen, afgezien nog van de potsierlijke mogelijkheid, dat hij er halverwege in zou zijn blijven steken.

$\mathrm{Na}$ een paar uur besteed te hebben met opmeten, teekenen, op dun papier afwrijven van de ornamenten en aanteekeningen maken, gedurende welken tijd al het volk en ook de voorname Baliërs in een grooten halven kring voor het tempeltje hadden zitten wachten, kroop ik weer te voorschijn en liet, op den beganen grond weder aangeland, mijn teekeuingen zien aan dengene dien ik voor den Tjokorda hield. Deze bleek echter een bloedverwant van den Tjokorda te zijn; hij was een en al verbazing en béweerde herhaaldelijk: "Een Baliër zou er dat niet levend hebben afgebracht". De trom namelijk staat in een bijzonderen reuk van heiligheid; haar ook maar even aanraken veroorzaakt minstens zware ziekte, zoo niet den dood. De ambtenaar $\mathrm{V}_{\text {ALCK }}$, die in 1875 een bezoek aan Pedjeng bracht, had er even tegen geslagen om zich van het geluid te overtuigen, aan welke heiligschennis hij het (volgens de Baliërs) te danken had dat hij zich den volgenden dag onwel gevoelde en tot de medicijnkist de toevlucht nemen moest. ${ }^{1}$

Het daarop volgende jaar werd de controleur Liefrinck bij het bezichtigen der "klok" omstuwd door een groote en oogenschijnlijk onvriendelijk gezinde volksmenigte, die zijn doen en laten nauwkeurig gadesloeg, maar, volgens eigen zeggen ${ }^{2}$, kreeg hij door kalm enkel toe te kijken, toch geen overlast. Op verzoek van deu bloedverwant van den Tjokorda, bracht ik dezen laatsteu, den TJokonda Gedé Poéroe, een bezoek in diens woning; ook deze was vol belangstelling voor de teekeningen.

1 R. vas Eck, "Schetsen van het eiland Bali", Tïdschr. v. Ned.-Indië 1880 , I, p. $130-131$.

2 Rouffaer, „Een paar aanvullingen over bronzen keteltrommen in Ned.Indië", Bijdragen tot de Taal-, Land- en Volkenkunde van Ned.-Indië, 6 Volgr., deel VII (1900), p. 288, noot. 
Voldaan over de eerste resultaten van mijn onderzoek, keerde ik op het heetst van den dag, gedeeltelijk langs een anderen weg, door het antieke plaatsje Bĕdoeloe ${ }^{1}$, naar Gianjar terug.

Den volgenden dag kuierde ik weer naar Pedjeng, om den tempel verder te onderzoeken, en om het tentje, waarin de trom, uitwendig af te beelden.

Dadelijk na mijn komst bij den tempel herhaalde zich dezelfde vertooning van den vorigen dag, en werd ik weder door een groote menigte omstuwd. Op het tempelplein vond ik in een drietal steenen huisjes, die, evenals het tentje voor de trom, op een hoog voetstuk stonden, een groot aantal fragmenten van oude Hindoe-beelden. Tegen elk huisje moest ik weder opklauteren, daar ook bij deze een trapje ontbrak.

In het bericht van Liefrinck over de Pedjeng'sche keteltrom staat: "Men klimt er met een steenen trapje heen". Waarschijnlijk zijn dus na diens bezoek zoowel het steenen trapje uaar de trom, als de opgangen naar de andere gebouwtjes gesloopt; waar ze aan de voetstukken aansloten zijn de moeten nog duidelijk te onderkennen. ${ }^{2}$ Dat men mij stil liet begaan, moet daaruit verklaard worden dat ik de dorpelingen voor een voldongen feit stelde met mijne eerste beklimming, en dat dan de Inlandsche aard zoodanig is dat deze denkt: "moet hij gestraft daarvoor, dan zullen de Goden hem wel straffen". Door mijn teekeningen had ik daarnà de sympathie der Baliërs mij blijkbaar verzekerd.

Onder de talrijke fragmenten in de drie tempeltjes bevonden zich velé lingga's en eukele joni's; $1 \frac{1}{2}$ meter hooge figuren, zittend op ineengekronkelde slangen, zeer streng en sober van lijn; eenige Ganeça's, staand en zittend, en een brokstuk van een olifant met een man op den rug; overblijfsels van de pooten van een reusachtigen Nandi, verschillende groepen (Çiwa met Dewi Çri) en eenige mannelijke ${ }^{*}$ beelden met zeer eigenaardige koppen (vermoedelijk wel portretbeelden ${ }^{3}$ ); een aantal staande vrouwenfiguren, en een ontelbare menigte door den tijd geheel ouherkenbaar geworden steenbrokken

1 Dat deze plaats heel vroeg zeer belangrijk al was, blijkt uit de Nagarakertâgama (van $1365 \mathrm{~A}^{\circ} \mathrm{D}$.), waarin als één der twee plaatsen op Bali voorkomende dit Bědoeloe of Bědahoeloe ("Badahulu") in Gianjar genoemd wordt naast een tweede plaats, "Lwâ-gadjah", waarvan de ligging nog niet bleek. Zie Encyclop. v. Ned-Indië IV [1905], i. v. "Tochten”, p. 385, 1• kol.

2 Zie Plaat I.

3 Verg. het merkwaardige opstel van den heer Grofneveldt in Tijdschr. Bat. Gen. L (1907), p. 140-146, met 3 platen. 
en op een altaartje eenige stukken koraal. Ten laatste nog een brokstuk waarop sporen van ingebeitelde schriftteekens, doch zóó verweerd en vergaan, dat zij bij het afwrijven op dun papier, jammer genoeg, geheel onherkenbare moeten achter lieten.

Het type van al deze beelden, voor zoover herkenbaar, wijkt volkomen af van het tegenwoordig op Bali vervaardigde beeldhouwwerk, maar komt geheel overeen met dat vau de op Java gevonden Hindoe-beelden uit de laatste, de Modjopahit-periode.

Waarschijnlijk zijn ze dus òf uit den laatsten tijd der overheersching van Bali door de Hindoe-Javanen (stel dus uit de $15^{\text {de }}$ eeuw), òf, wat ook mogelijk is, ze zijn bij het geleidelijk ineenstorten van Modjopahit (omstreeks 1500) door Javanen uit het land hunner vaderen naar Bali medegevoerd; ò wel - wat minstens even waarschijnlijk kan zijn - ze zijn jonger van maaksel (zeg b.v. uit omstreeks 1600), maar in een ouderwetschen stijl, die op Java-zelf toen reeds geheel tot het verledene behoorde.

In 1897 verscheen er een prachtwerk, "Bronzepauken aus SüdostAsien" van Dr. A. B. Meyer en Dr. W. Foy waarin zij alle, hun bekende, trommen opsommen en uiterst nauwkeurig beschrijven.

Hun lijst van 51 stuks geeft een 10 -tal in onze Oost voorkomende exemplaren, doch makt in 't geheel geen melding van de trom van Bali, hoewel daar toch reeds meer dan één bericht van bestond.

De heer Rouffaer gaf daarop in ziju artikel "Een paar aànvullingen over bronzen keteltrommen in Ned.-Indië" ${ }^{1}$, als aanvulling op bovengenoemd werk een overzicht van wat vroegere schrijvers omtrent de Pedjeng'sche trom hadden medegedeeld, en was de eerste die de andacht weer vestigde op een merkwaardige mededeeling van Ruмrнuus in dieus "Amboinsche Rariteitkamer", als "waarschijnlijk de oudste" mededeeling op dit gebied in het Nederlandsch, misschien wel tevens in "eenige Europeesche taal". ${ }^{2}$

ROUFFakr acht dit bericht afkomstig van HeNrIK LEYDEKKER, die meermalen op Bali was geweest en dien ook VALENTrsN bij zijn beschrijving van Bali tot zegsman was. Bij VALENTIJN wordt de trom echter niet vermeld. Dan haalt Rouffakr aan het bericht dat, bijkans twee eeuwen later, vaN Eck gaf in zijn bekende "Schetsen

1 In deze „Bijdragen", 6• Volgr., deel VII (1900).

2 D'Amboinsche Rariteitkamer, Amsterdam 1705, fol. 207. 
van het eiland Bali" op gezag van de twee reeds even genoemde waarnemers uit 1875 en 1876 .

Het bericht van 1875 is van den ambtenaar $V_{\text {ALCK, die' spreekt }}$ van een enorm groote gong. De tweede berichtgever, LIEFrinck, is wat uitvoeriger: "Zij heeft veel van eeue torenklok, die op haar kaut ligt en is ongeveer 1 meter lang. De voorzijde bestaat uit eene platte schijf van ongeveer $1 \frac{1}{2}$ el diameter". In een noot (l. c. p. 288, noot 1) zegt Rouffakr: "Rumphius gaf deu diameter van 't bovenvlak als \pm 4 (Amst.) voet, dus \pm 1.15 M.; Liefrinck zegt $\pm 1.50 \mathrm{M}$; een bewijs te meer, dat de zegsman van Rumphius het stuk zelf gezien heeft. 1 Doch RuмpHius geeft "de as" op "als ruim zoo lang", d. i. dus grooter hoogte dan diameter, wat een fout is èn blijkens LIEFrinck èn uit den aard van zoo'n keteltrom".

Evenwel, - de trom van Pedjeng wijkt wat verhouding van hoogte tot diameter betreft, af van àlle tot nu toe bekende trommen, en het bericht van LIEFrInck is onjuist; niet te verwonderen dus dat RouffaEr een verkeerde gevolgtrekking maakt. Want, hoewel LIFFrINCK met zijn opgaaf vau den diameter dicht bij de waarheid was $^{2}$ (deze is in werkelijkheid - zie Pla at II - $1.60 \mathrm{M}$. ), geeft hij de lengte verkeerd op; deze toch is $1.86 \frac{1}{2}$ M., mérér dan manshoog, en dus niet "ongeveer 1 meter". Ruмpнius echter - of liever zijn zegsman, LEYDEKKER (?) - met zijn "ruim zoo lang" had dus hieriu volkomen gelijk; maar slaat in een ander opzicht, waar hij iets verder van dit prachtig bewerkte stuk spreekt, als van "een onvormelijke klomp" de plank toch ook weer glad mis.

"In het midden (van de voorzijde)" zoo luidt verder het bericht van LIEFrinck, "is een achthoekige ster aangebracht, waaromheen 24 andere sterren staan, allen door stralen omgeven. De cylinder is versierd met vier menschenhoofden ${ }^{3}$ en ander snijwerk". Ook dit heeft Lrkrrrinck niet juist gezien.

In het midden van de door de Baliërs dusgenaamde "maan" — zie de teekening van één kwart-deel op Pla at III - bevindt zich een achtstralige ster, omgeven van een breeden band die gevuld is met sierlijke, onberispelijk getrokken golflijnen en cirkels, die zich

1 Nog een ander bewijs daarvoor is: dat de trom in het bericht van LEXDEKKFR wordt vermeld als te zijn "blauwachtig of zwart uitgeslagen", wat volkomen met de werkelijkheid overeen komt.

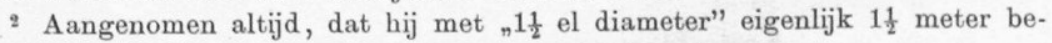
doelt, zooals Rouffaer aanneemt; en geen oude nel".

3 Waarnaar ik deze trom heb genoend: "De trom met de hoofden". 
slingeren om 20 middelpunten; van 24 sterren met stralen is geen sprake, terwijl de cylinder met acht menschenhoofden prijkt, geenszins met vier.

Naar aanleiding van een passage in de Oesana Bali, een aanteekening van Friederich, en een afbeelding bij IJzerman, komt Rouffaer (l. c. p. 291-292) tot de volgende gissing: "Doch is het, dan gewaagd als gissing ook dit daaraan vast te knoopen: zou de keteltrom van Pedjeng niet, als wreed variant op haar oorspronkelijke goedmoedige bedoeling, inderdaad ook als ketel hebben dienst gedaan warin menschen levend gekookt zijn geworden; zouden de vier menschenhoofden d a arop a angebracht, niet de herinnering moeten vasthouden aan een dergelijke wreede lijfstraf?

Zeker, de huidige overlevering, en die welke Ruмrнius kende, zwijgt er van. Reden te meer, dat deze Pedjeng'sche keteltrom antiek moet zijn, evengoed als de tempel. Maar de coïncidentie in de Oesana Bali is toch te wonderlijk, om ten minste de vraag niet te durven stellen. Blijkt, bij later nauwkeurig onderzoek, een "Ja!" te mogen volgen, dan dwingt de logica aan te nemen, dat aan deze keteltrom later op Java of op Bali-zelf die bronzen menschenhoofden zijn to egevoegd geworden; iets, wat bij de ervarenheid in metaal-bewerking der Hindoe-Javanen en Baliërs, geen bezwaar hoegenaamd kan zijn."

Had Roufraer het voorwerp zelf kunnen zien of hadden hem nauwkeurige afbeeldingen ten dienste gestaan, hij zou ongetwijfeld dadelijk deze conclusie weder verworpen hebben.

Was de trom werkelijk als ketel tot het koken van boosdoeners gebezigd, en waren de hoofden later aangebracht, dan zouden deze niet staan zooals ze nu staan. Kon men de trom als ketel ophangen, dan zouden in dat geval de hoofden naar omlaag staán — verg. Pla at II - , onderstboven dus zijn a a gebracht met de lange, door zware oorringen uitgerekte oorlellen naar omhoog! Doch deze beschouwing kan gerust buiten rekening worden gelaten, daar, zooals bij 't onderzoek mij onmiddellijk bleek, de hoofden één geheel vormen met de trom, tegelijk dus zijn mede-gegoten, niet later zijn toegevoegd.

Dit hoofden-ornament - zie Pla at IV - is, evenals het meeste andere ornament op de trom, slechts gevormd uit dunne, ongeveer $2 \mathrm{mM}$. hooge opstaande randjes (alleen de neuzen steken verder naar voren, terwijl de oogen knoppen, halve bolletjes, zijn) welke 
randjes onmiddellijk staan op het oppervlak van de trom zelf. Het zijn dus geheel vlakke koppen, niet met sterk relief uitstekende halve hoofden, zooals we zoo vaak hier in Europa op voorwerpen of op huizen zien aangebracht.

Ik wil hierbij ten overvloede opmerken, dat het laug niet zoo gemakkelijk is, integendeel bijna ondoenlijk, aan eeu eenmaal gereed zijnd gegoten werkstuk iets toe te voegen, zóó dat dit niet spoedig te zien valt. Dat de vervaardigers - en dit waren werkelijk bewonderenswaardig handige gieters - dit ook maar niet zoo kondeu, blijkt ten duidelijkste aan de negen ingelaschte stukjes in de drie reeksen van drie gaatjes ${ }^{1}$ in het klokvormig benedengedeelte, welke invoegingen duidelijk in 't oog springen. ${ }^{2}$

In 1902 verscheen weer een groot prachtwerk over Oostersche keteltrommen: "Alte Metalltrommeln aus Südost-Asien" van Franz Heger, Directeur van het Naturhistorisches Hofmuseum te Weeneu, waaraan deze, volgens zijn voorrede, meer dan 18 jaren had gearbeid.

Vermeldden Meyer \& For ruim een vijftigtal trommeu, Heger geeft een beschrijving van nog een honderdtal meer exemplaren en vermeldt nu ook de trom vau Bali met verwijzing naar het reéds besproken artikel van RoufFaER.

Verdeelden Mexer \& Foy hun materiaal in 6 groepen, Heger rangschikt zijn trommen-drommen in vier "Haupttypen", welke hij (naar zich zelven) noemt: "Heger I-Heger IV", waarnevens nog een 3-tal overgangsvormen. ${ }^{3}$

1 Zie over deze gaatjes en hun noodzakelijkheid blz. 335 hierachter, en vergelijk Plaat II, op welke twee maal drie van deze gaatjes te zien zijn.

2 In verband hiermede nog een aanhaling uit het dadelijk te noemen werk van Heger (p. 51, kol. 2), waar deze bij de bespreking van eenige gaatjes in een zekere trom het volgende schrijft: ${ }_{n}$ Es ist wahrscheinlich, dass diese Löcher schon beim Gusse entstanden sind und nicht etwa in Folge von Rostbildung durchgefressen wurden. Daraufhin deutet schon die ziemlich regelmässige Umgrenzung derselben sowohl auf der äusseren, wie auf der inneren Fläche des Mantels. Sie stammen daher wohl von den herausgefallenen Nachgussen der durch die Stützen beim Gusse entstandenen Löcher her."

3 De indeeling van HEGER is als volgt:

I. Typus I ("Heger I"), „der Grundtypus". Daarvan 35 stuks, waaronder Saleier, Roti, Bali, Leti, Loeang, 4 te Batavia en 2 te Leiden.

a. Uebergangsform I rv; Gruppe A, 5 stuks, waarvan 1 te Leiden; Gruppe B, 1 stuk; Gruppe C, 4 stuks waarvan wederom 1 te Leiden. 
Tot Type I rekent hij ook de trom van Bali. Zooals echter uit de volgende bladzijden duidelijk zal blijken, wijkt de trom met de hoofden in zóóveel opzichten af niet alleen van de trommen van dit eerste type, maar van alle tot nu toe bekende exemplaren, dat ik vermeen haar gerust te mogen bevelen uit het gelid "Heger I" te treden, om voorloopig maar alléén te blijven staan, desverkiezend bij het andere in de noot vermelde "Fragezeichen", en heelemaal vóórop.

$* * * * * * * * *$

De trom te Pedjeng heeft een hoogte van $186 \frac{1}{2} \mathrm{cM}$., terwijl de doorsnede van het plat $160 \mathrm{cM}$. bedraagt. Om duidelijk aan te toonen, welk een geweldige afmetingen dit voor een trom ziju, heb ik naar de opgaven bij HEGER, de gemiddelde maat berekend van de trommen van het eerste type, dat de grootste bekende exemplaren bevat; de uitkomst was pl. m. 50 centimeter voor de hoogte, pl. m. 70 voor de doorsnede. ${ }^{1}$

De trom van Pedjeng is dus $3 \frac{3}{4}$ maal zoo hoog als de gemiddelde trom van Type $I$ en de doorsnede van het bovenvlak is $2 \frac{3}{10}$ maal de doorsnede daarvan.

Een andere trom in onze Oost, die op Saleier, kon, vóór ik de maten van Pedjeng had vastgesteld, als het grootste stuk worden beschouwd, zooals Heger dan ook schrijft: ${ }^{2}$ "jedeufalls das grösste bis heute bekannte Stück dieser Art". De Pedjeng'sche is echter meer dau nog eens zoo hoog, de doorsnede van het bovenvlak

b. Uebergangsform H I II, 3 stuks.

II. Typus II (H II), 13 stuks.

c. Uebergangsform II $\mathbf{i v}, 1$ exemplaar.

III. Typus III (H III), 20 stuks.

IV. Typus IV (H IV), 62 stuks, waarvan 2 te Leiden.

Dan volgt er nog één enkele trom (uit Tonkin) die HEGER geen kans ziet in zijn zoo naarstig georganiseerde trommenreeksen in te voegen, want daaraan ontbreken kenteekenen die bij alle andere trommen regelmatig wederkeeren. "Diese Trommel", zoo schrijft hij op p. 17 ,steht in der langen Reihe der angeführten Stücke wie ein grosses Fragezeichen da". We zullen zien dat de Pedjeng-trom nog een véél grooter vraagteeken is.

1 Bij de berekening heb ik een bijzonder klein exemplaar (bij Heger met No 20 gemerkt) buiten beschouwing gelaten, daar dit zoo'n miniatuurtje is (hoogte 3.8 , doorsnede $6.4 \mathrm{cM}$.) dat we vermoedelijk met een model op kleine schaal (op to ?) of met speelgoed te doen hebben.

2 P. 28 , kol. 1. 
meer dan één derde grooter. (De Saleier'sche is hoog $92 \mathrm{cM}$. met een doorsnede van boven van $126 \mathrm{cM}$.) ${ }^{1}$

Nog duidelijker komt de alles overtreffende hoogte van onze Pedjeng'sche reuzin uit op $\mathrm{Pl}$ a a $\mathrm{VI}$, waar haar profiel in 't midden is afgebeeld, omringd door de in eenzelfde verhouding geteekende profielen van de typen van MEYER en Foy, ${ }^{2}$ vermeerderd met het profiel van Saleier. ${ }^{3}$

Behalve het verschil in grootte is er nog een uiterst merkwaardig on'derscheid tusschen Pedjeng en de trommen van Type I. Bij deze laatste staat volgens de zooeven gegeven getallen, de gemiddelde hoogte tot de gemiddelde doorsnede van het bovenvlak als 5:7, Pedjeng als 18,6: 16; de verhouding is hier dus juist omgekeerd. Zijn al de tot nu toe bekende trommen (niet alleen die van Type I, maar ook alle audere exemplaren) meer breed dan hoog, die van Pedjeug is meer hoog dan breed.

Een derde merkwaardige afwijking is het buitengewoon ver uitsteken van het bovenvlak buiten het lichaam, n.l. 25 c.M. Immers, bij de beschrijving van de stukken van Type I, heet het bij Heger meest: "Die Platte ragt nur wenig über den Mantel hervor"; van enkele stukken geeft hij daarvau maten, en is de grootste mat van dat overstek 2,8-4 cM. Op p. 133 lezen we bij Heger: "Bei den Uebergangsformen IIv ist immer ein, wenn auch meist nicht bedeutendes Vorspringen der Platte zu constatiren... Bei der Uebergangsform III ist diese Ausladung der Platte immer sehr beträchtlich und erinnert dadurch schon an den Typus II. Bei Hsi V (verg. I) biegt sich wahrscheinlich sogar der Rand senkrecht nach unten um, was sonst nur bei dem genannten Typus vorkommt.

1 Meyer, Alterthümer, pag. 15 b; Mexer \& Foy, Bronzepauken pag. 1 b.

Zie vooral over de trom op Saleier de in 1903 verschenen belangrijke mededeeling van (․ W. W. G. Baron vaN Hö̈vell (waarbij zeer goede afbeeldingen), waaraan Dr. J. D. E. Schmeltz eenige beschouwingen vastknoopt: „Mitteilungen über die Kesseltrommel zu Bonto-Bangun, (Insel Saleyer)”, Intern. Archiv für Ethnographie, Bd. XVI, 1903, p. 155-157, met plaat XX-XXI.

2 Overgetrokken van de afbeeldingen op Plaat XIII van hun werk.

3 Gemaakt naar de af beelding bij HEGkr (Tafel VI) welke echter niet geheel juist is. De afbeelding bij Baron van HoËvell (Int. Areh. f. Ethnogr., Bd. XVI, Taf. XXI), die mij echter pas in handen kwam, nadat het cliché voor mijn Plaat VI reeds gereed was, vertoont namelijk een meer duidelijken overgang van het boven-mantelgedeelte naar het midden-gedeelte; voor ons doel, om de hoogte met die van de Pedjeng'sohe trom te vergelijken, makt dit echter geen verschil. 
Die Trommel Wien XIX $(=\mathrm{V})$ hat einen Plattenvorsprung von durchschnittlich $2.8 \mathrm{cM}$.

Bei allen Trommeln vom Typus II findet ein nicht unbeträchtliches Vorspringen der Platte über den Mantel statt. Bei manchen dieser Stücke biegt sich der Rand nach unten senkrecht um und lässt daher denselben breiter erscheinen, als die Metalldicke der Platte beträgt. Am besten is dies bei der Trommel Wien, Handelsmuseum sichtbar. Am bedeutendsten ist dieses Vorspringen der Platte bei der Trommel Hongkong $39{ }^{1}$, doch beträgt die Ausladung hier auch nur $4.25 \mathrm{cM}$., ohne dass sich der Rand nach unten umbiegen würde.

Das eine Uebergangsstück II Iv hat nur einen sehr kleinen Vorsprung der Platte über den Mantel aufzuweisen.

Ziemlich beträchtlich ist das Vorspringen der Platte bei allen Vertretern des Typus III, wo dasselbe immerhin bis $3.5 \mathrm{cM}$. beträgt....

Bei den Trommeln vom Typus IV findet in dieser Beziehung ein ähnliches Verhältniss statt, wie bei jenen vom Typus I, uur dass ein stärkeres Vorspringen der Platte verhältnissmässig noch seltener vorkommt. Sehr häufig findet ein fast unmittelbarer Anschluss zwischen Platte und Mantel.... statt".

Uit het bovenstaande valt aanstonds op, hoe luttel het vooruitsteken van het bovenvlak buiten het lichaam van de neeste trommels is, en tevens zien we dat $4 \frac{1}{4}$ centimeter mag worden angenomen als het tot nu toe bekende grootste overstek. Oók in dit opzicht is dus de trom van Pedjeng met $25 \mathrm{cM}$. overstek weder een unicum.

$\mathrm{Om}$ het bovenvlak van de trom met de hoofdeu vindt men verder een, in de richting van het lichaam vau de trom, haaks omgebogen rand van $2.7 \mathrm{cM}$; een dergelijke neergaande rand komt maar bij weinig trommels voor, en bij geen enkele der door HeGER onder Type I gerangschikte. Wèl is deze rand bij de trommen van HeGER's tweede type, o. a. bij de trom uit het Handelsmuseum te Weenen, te vinden, welke trom door MEYER en Foy echter tot hun eerste type gerekend wordt, m. i. zeer terecht. ${ }^{2}$

Bij beschouwing van Plaat VI valt al aanstonds nog een merkwaardigheid op van de trom van Pedjeng, n.l. de bijzonder scherp gemarkeerde afscheiding tusschen de drie

1 Bedoeld wordt zeker "Canton 39", No 7 van Type II.

2 Zie voor het profiel van deze trom mijne Pla at VI, links onderaan, profiel I, welke overigens in beloop van lïn ook het meest orereenkomst toont met de Pedjeng-trom. 
gedeelteu, waruit het lijf van de trom zooals gewoonlijk is saamgesteld; bij al de bij Heger vermelde exemplaren toch wordt die afscheiding hoogstens gevormd door een rand, of is deze zelfs nauwelijks meer merkbaar. Ook het lijnrechte profiel van het middengedeelte heb ik bij geen ander stuk kunnen ontdekken. Er zit, zoo te zeggen, een krachtige architectonische stijl in de Pedjeng-trom.

Ook de hengsels of ooren ziju zéér merkwaardig. Ten eerste zijn deze opvallend groot en breed, wat duidelijk uitkomt op $\mathrm{Pla}$ a $\mathrm{V}$ (rechts), waar een van de ooren vlak uitgespreid is afgebeeld in eenzelfde verhouding als het breedste oor dat Heger geeft en dat door mij, ter vergelijking, in den rechter bovenhoek van de teekening geplaatst is. Ten tweede zijn deze ooren niet zooals meestal het geval is, bandvormig - dat is dus: overal even breed - of, zooals een enkele maal voorkomt, in het midden smaller dan aan de inplauting ${ }^{1}$; maar juist omgekeerd, in het midden breeder dan bij de plaats van aanhechting.

Zooals gewoonlijk zijn de hengsels zoo geplaatst dat ze deu overgang van het bovengedeelte naar het middengedeelte overbruggen. Doch zijn bij alle andere exemplaren de hengsels twee an twee, bij de eene weliswaar wat verder uiteen staaude dan bij de andere, maar toch steeds tot twee paren gerangschikt, - bij de Pedjeng'sche sta an de hengsels gelijkelijk over den omtrek verdeeld, met even. groote tusschenruimte dus, en niet in paren.

Wijkt het uiterlijk van de Pedjeng'sche trom dus in alle opzichten af vau de "Metalltrommelu" van HEGER, daarentegen stemt dit weer merkwaardig overeen met de moko's van Alor, waarop de heer vAN HoËvELL mij attent makte.

Ook bij deze moko's ${ }^{2}$ bedraagt de hoogte veel meer dan de middellijn van het boveuvlak, en steekt dit laatste naar verhouding

1 Zie toch de 12 hengsels bij Heger afgebeeld op zijn Tafel XXIX.

${ }^{2}$ Zie de af beelding van een exemplaar uit Leiden in het „Intern. Archiv für Ethnogr." Band XV, pag. 33, behoorende bij „Messingtrommeln von Alor" door Dr. J. D. E. Schmeltz.

Behalve deze af beelding kwamen mij nog onder de oogen twee foto's die door den posthouder op Alor, den heer J. W. Mrelemans (die ook de moko aan het Museum te Leiden ten geschenke gaf), aan de bibl. van het Kon. Inst. voor de T.-, L.- en Volkenkunde van N.-I. te Den Haag in 1900 gegeven waren. Op de eene foto (Familie van den radja van Blanjar (Alor) met zijn lievelings-moko) zijn 3 moko's te zien, op de andere een groep van 14 stuks. 
ver buiten den mantel uit (zonder omgebogen rand echter); ook de scherpe afscheiding der drie mantelgedeelten bij de moko's heeft veel meer van die van de Pedjeng'sche trom dan eenige "Metalltrommel". Het profiel van de drie mantelgedeelten afzonderlijk vertoont ook een buitengewone gelijkenis met dat van de drie gedeelteu bij de Pedjeng'sche trom, vooral bij het klokvormig beneden-stuk. Nog een belangrijke overeenkomst bestaat daarin dat bij de moko's de 4 ooren (slechts enkele van deze voorwerpen schijueu geen ooren te hebben) evenver van elkaar staan, dus niet in twee paren; juist dus zooals bij de trom met de hoofden, hetgeen bij deze trom zoo'n belangrijk verschilpunt vormt met de andere trommen. Ik zou d us hast geneigd zijn onze trom eeu reusachtige moko te noemen; in grootte blijft onze Pedjeng'sche reuzin toch boven alles uitsteken, daar volgens de voor mij liggende foto's de Alor'sche moko's slechts een 50 tot $75 \mathrm{cM}$. hoog kunnen zijn. ${ }^{1}$

Op enkele van die moko's komen als versiering ook menschenhoofden voor, op het Leidsche exemplaar zelfs wajang-achtige menschenfiguren; toch lijken mij deze hoofden vooralsnog moeilijk in verband te kumnen worden gebracht met de hoofden van de Pedjeng'sche trom.

En nu de versiering van de trom.

We beginuen bij de ornamenteering van het ronde boveuvlak, dat in 5 gedeelten valt te ouderscheiden: in 't centrum $1^{\circ}$ de ster; daaromheen $2^{\circ}$ een smalle band die de ster omsluit eu afscheidt van $3^{\circ}$ de breede versierde hoofdstrook; waaromheen $4^{\circ}$ een dergelijke band als sub 2 ; en ten laatste als $5^{\circ}$ de geheel vlak gehoudeu buitenste strook. Zie Pla at III.

De ster is geheel vlak en $\frac{1}{2}$ cM. hoog; ze heeft acht stralen, die uit het middelpunt gerekend $12 \mathrm{cM}$. lang zijn. Om de ster zijn op het bovenvlak van de trom opstaande raudjes, die in 't verlengde vau de stralen doorloopen tot op een op $24 \mathrm{cM}$. uit het midden getrokkeu cirkel. In het verlengde van 4 der stralen loopt nog een randje door, door band 2 en 3 , deze beide in 4 gelijke parten verdeelend.

De versiering van de 8 vakken tusschen de sterpunten is op Plaat III te zien. Twee hoeken zijn elk gevuld met elf steeds kleiner wordende booggedeelten; voor het overige vertoont elk vak

1 Het Leidsche exemplaar is hoog $37 \mathrm{cM}$., met een doorsnede van het bovenvlak (dat $2.2 \mathrm{cM}$. vooruitsteekt) van $23 \mathrm{cM}$. 
een knop, een halven bol (slagheuveltjes?), waaromheen een paar cirkels zijn getrokken.

Heger geeft in zijn werk op Tafel XXXI 51 afbeeldingen van verschillende ornamenteeringen der ruimten tusschen de sterpunten, en in zijn tekst op p. 242 en 244 er nog twee; maar geen enkele dezer 53 teekeningen komt overeen met wat Plaat III te zien geeft; knoppen als bij onze trom heb ik bij geen enkele kunnen ontdekken.

Band 2, die $6 \frac{1}{2}$ cM. breed is, wordt gevormd door $3 \times 3$ cirkelomtrekken (opstaande randjes, zooals al het lijnornament op 't plat en ook op 't lichaam van de trom), wartusschen twee maal 4 reeksen streepjes van ongeveer $4 \mathrm{mM}$. lengte.

Dan volgt $3^{\circ}$ : de $21 \mathrm{cM}$. breede band met de voornaamste versiering, welke met een wonderbaarlijk meesterschap is aangebracht en moeielijk te beschrijven valt. Pla a III geeft echter een nauwkeurige afbeelding van én vierde gedeelte, ingesloten tusschen twee door dezen band doorloopende verlengstukken van stralen uit de middenster; de drie andere vierde-deelen stemmen volkomen met dit door mij afgebeelde gedeelte overeen; men deuke zich alles op gelijke wijze slechts in de rondte voltooid.

Op Plaat III dan ziet men in band 3,5 knoppen, waarvan de twee buitenste ook tot twee aausluitende vierde-parten van den geheelen band behooreu, zoodat er in 't rond in 't geheel 16 knoppeu staan. Op den geheelen hoofdband komen 20 middenpunten voor (de "24 sterren" van LIEFrINCK), waaromheen zich de prachtige golflijnen cirkelen, n.l. de zooeven geuoemde 16 knoppen phus 4 plekken waar zich géén knop bevindt, maar waar men het uiteinde van een soort lus gewaar wordt, welke lus loopt tot an de knoppen die zich op de 4 doorloopende stralen van de middenster verheffen; deze laatste knoppen zijn zelf weer met de daarop volgende knoppen door een baud of lus verbouden. ${ }^{1}$ Ook dit ornament heb ik op géén andere trom kunnen ontdekkken.

1 Zooals boven reeds werd vermeld, vertoont geen andere trom knoppen of ronde heuveltjes als de. Pedjeng'sche tusschen de sterpunten, en in de geornamenteerde hoofdstrook op het bovenvlak. In het belangwekkende opstel van Prof. pe Groot (Versl. en Meded. der Kon. Akad. van Wetensch. Vierde reeks, II (1898), 347) komt echter een aanhaling voor uit een Chineesch boekske uit de dertiende eeuw, naar welke aanhaling ik meen te mogen besluiten dat daar toch sprake is van een trom met dergelijke knoppen: „In Ma-yang bezit men een bronzen trom.... $\mathrm{Z}_{\mathrm{ij}}$ gelijkt op een groote klok... en 
Wat stelt deze met wiskunstige zuiverheid getrokken versiering nu voor? Zijn de golflijnen golven of wolken? Dit laatste zou nog wel aanneembaar zijn; maar wat zijn dan die raadselachtige lussen? Zijn al die knoppen weer slagheuveltjes? Altemaal nieuwe raadsels, warop ik geen antwoord vermag te geveu, en die vermoedelijk ook wel niet zoo spoedig opgehelderd zullen worden.

Band 4 is voorts gelijk band 2, alleen met dit onderscheid, dat band 4 breeder is ( $8 \frac{1}{2}$ cM.), en niet met $2 \times 4$ maar met $2 \times 5$ stippelreekse.1-versierd is.

$\mathrm{Nu}$ volgt $5^{\circ}$ de geheel vlakke $20 \mathrm{cM}$. breede band, waaraan de haaks naar beneden omgebogen $2,7 \mathrm{cM}$. breede band.

Van sub $\mathbf{5}$ is het noodzakelijk te vermelden wat er niet op te zien valt; er zitten namelijk geen kikkers of andere figuren op, zooals op de meeste tot uu toe ontdekte trommen wèl. En er zijn ook absoluut geen sporen, die er op zouden kunnen wijzen dat deze er vroeger op gezeten hebben.

$\mathrm{Nu}$ de versiering van het lichaam of den mantel.

Aan het bovenste, $67 \mathrm{cM}$. hooge gedeelte van den drieledigeu mantel, zien we als eerste ornament op $6 \frac{1}{2} \mathrm{cM}$. afstand van het bovenvlak, elf scherpe, opstaande, iets meer dan $1 \mathrm{cM}$. ran elkaar verwijderde en bijna $1 \mathrm{cM}$. hooge ribben, gevolgd door een even hoogen $3 \frac{1}{2}$ cM. breeden band; zie de profielteekening op $\mathrm{Pl}$ a a $\mathrm{V}$, links.

$\mathrm{Op}$ een effen strook, volgt dan (zie Plaat IV) een $14 \mathrm{cM}$. breede band, die geheel gevuld is met randen, 4 reeksen op- en nederwaarts wijzende spitsen of toempal's, en één reeks $f$-vormige figuurtjes. 1

Elk zoo'n $f$-vormig figuurtje is een tot een eenvoudig ornamentje gestileerd vogeltje. ${ }^{2}$

Doch nu volgt het allermerkwaardigste ornameut van de trom. Onder aan den zooeven beschreven breeden baud met

heeft zes-en-dertig tepels (bulten)," De Pedjeng'sche trom heeft er op het bovenvlak 24 , n.l. de 16 genoemde van band 3 , plus de 8 groote slagheuveltjes (?) van den binnensten kring.

1 Op Plaat IV is een gedeelte van dezen band op $\frac{1}{2}$ nat. grootte afgebeeld.

2 Voor den overgang van vogeltje tot ornamentje zie men bij MErer en en Fox plaat XI, fig. 7, 8, 9, 10 en ook 47, en bij Heger plaat XXXV, fig. 37,37 a en 37 b. 
toempal's en vogeltjes sluiten zich op vier plaatsen, tusschen de vier hengsels, een tweetal ovale menschenhoofden aan (in 't geheel dus acht), die rusten op een smal bandje met één reeks toempal's, welk bandje het eerste mantelgedeelte van onderen begrenst. Zie Plaat I V.

Van alle koppen is de ver vooruitstekende neus beschadigd. De oogen zijn gevormd door halve bolletjes, evenals de slagheuveltjes (?) op het bovenvlak; de fraai gevormde lippen steken iets verder vooruit dan de omringende randjes, welke baard, bakkebaarden en suor moeten voorstellen. Merkwaardig vooral ook zijn de verbazend lang uitgerekte ooren met de muntvormige oorhangers.

Wat die koppen met hun zonderling starende oogen-verbeelden? Zoo aanstonds zal ik trachten die vraag te beantwoorden, doch eerst wil ik het verdere ornament op de trom afhandelen.

De overgang van het eerste tot het tweede mantel-gedeelte wordt gevormd door een $3 \mathrm{cM}$. breede inspringende strook; deze overgang is goed zichtbaar aan het profiel midden op Plat VI. Het tweede- of middengedeelte (zie Pla at II) dat $39 \frac{1}{2} \mathrm{cM}$. lang is, heeft tot eenig ornament een zelfden $14 \mathrm{cM}$. breeden band met toempal's en vogeltjes als op het boven-mantelgedeelte voorkomt, plus nog op 8 plaatsen, n.l. onder de 4 paar hoofden en onder de 4 hengsels, telkeus een kort stuk (16 cM. lang) van een zelfden band, die daar echter loodrecht er op staat. Deze nagenoeg vierkante stukjes eindigen boven in twee cirkelomtrekken.

De gedaante en versiering van de hengsels behoeft geen verdere beschrijving, daar $\mathrm{Pl}$ a a $\mathrm{V}$ deze duidelijk genoeg doet zien.

Evenals alle hengsels van alle tot nu toe bekende trommen, geen enkele uitgezonderd, zijn ook deze met een vlecht-motief versierd. Naar mijn meening wijst dit steeds herhaalde vlechtmotief op een bepaalde afkomst, en denk ik mij de hengsels der nu ontdekte trommen als een nabootsing in metaal van werkelijk (b.v. van rotan) gevlochten ooren bij een nog ouder type van (misschien wel houten) trommen; die dan aan lusseu werden opgehangen, zooals nu nog de gong's op Java.

De overgang tot het derde of onderste mantel-gedeelte wordt weder door eeı 3 cM. breeden, vlakken, nu uitspringenden band gevormd. Het klokvormig onderstuk, dat $80 \mathrm{cM}$. hoog is, heeft op 4 cM. afstand van den onderkant alleen één zoo'n zelfden band als op het midden- en bovengedeelte voorkomt, tot ornament; voor het overige is het geheele onderstuk vlak gehouden. Zie Pla at II. 
Al het bovenstaande samenvattend, zien we dat de keteltrom van Pedjeng in talrijke opzichten afwijkt van alle andere tot nu toe bekende bronzen keteltrommen, en dat ze vele zéér bijzondere merkwaardigheden vertoont, als met name:

$1^{\circ}$ de buitengewone grootte;

$2^{\circ}$ de verhouding van hoogte tot breedte;

$3^{\circ}$ het enorme overstek van het bovenvlak;

$4^{\circ}$ de bijzonder sterk sprekende afscheiding der drie mantelgedeelten;

$5^{\circ}$ het rechte profiel van het middenstuk;

$6^{\circ}$ de groote hengsels of ooren, die in het midden breeder zijn dan bij de plaats van aanhechting;

$7^{\circ}$ het op gelijken afstand van elkaar verwijderd zijn der hengsels of ooren;

$8^{\circ}$ het ornament tusschen de stralen van de ster;

$9^{\circ}$ het ornament op het bovenvlak met de golflijnen, de kuoppen en de raadselachtige lussen; en

$10^{\circ}$ de hoofden, acht in getal.

\section{$* * * * * * * * *$}

De trom ligt nu op haar kant, op eenige steenbrokken, zoodanig dat het groote ronde bovenvlak loodrecht omhoog staat. Op het plein vóór het tempeltje staande, ziet men alleen een gedeelte van dit ronde bovenvlak door het houten hekwerk heen. ${ }^{1}$ De zijkanten van het tentje bestaan voor een klein gedeelte uit hekwerk, voor het overige uit steenen muurtjes, die aansluiten aan den geheel steenen achterwand.

Vermoedelijk heeft de trom reeds eeuwen lang in een gebouwtje, althans onder dak gelegen, want betrekkelijk is ze nog zeer gaaf; en de versiering, zoowel op mantel als op bovenvlak, is nog zoo zuiver en scherp, alsof het stuk eerst kort geleden den kleivorm had verlaten. Alleen is de kleur van het metaal door oxydatie blauwachtig zwart, geheel zooals reeds de berichtgever van RuMpHius vermeldde; an het ondergedeelte ontbreekt voorts een groot brok ${ }^{2}$; één van de hengsels is voor de helft verdwenen; en, zooals reeds vermeld is, zijn alle neuzen der koppen min of meer beschadigd.

1 Zie Plat I.

2 Zie Plaat I I. 
Aan den $3 \frac{1}{2} \mathrm{cM}$. breeden, platten band die het bovengedeelte van den mantel tot versiering strekt, ontbreekt ook een stuk, terwijl dicht daaromheeu zich een vijftal gaatjes in den mantel bevinden. In de vlakke buitenste strook van het bovenvlak is een kleine barst.

De trom vertoont geen gietnaden - zooals de trommen van Type I-, en is dus "à cire perdue" gegoten; dat wil zeggen: op een kleivorm, die met een draaibaren mal is afgewerkt, is de trom eerst nauwkeurig in was aangebracht, daarna het wasmodel geheel met klei bedekt, toen de was uitgesmolten en de daardoor ontstane ruimte met klokspijs volgegoten. De $3 \times 3$ gaatjes in het klokvormig benedengedeelte - die zoo goed mogelijk gedicht zijn, maar toch nog duidelijk blijven te onderscheiden, zooals reeds hiervóór (p. 325) werd opgemerkt - , zijn ontstaan doordat op die plaatsen een stukje klei of iets anders moest worden aangebracht, om te maken dat de buitenste kleivorm niet tegen den binnen-vorm aan zou zakken, na het uitsmelten der was; ook de gaten in de hengsels danken hun ontstaan aan een zelfde oorzaak. Zie Plaat II.

Dit lijkt allemaal erg eenvoudig; is in werkelijkheid echter, vooral bij een stuk met de reusachtige afmetingen als de trom te Pedjeng, zoo moeielijk en ingewikkeld, dat het haast onbegrijpelijk lijkt, hoe er reeds zóó tal van eeuwen geleden in deze streken zulke eminente vaklui en kunstenaars aanwezig waren, die het verstonden een dergelijk gietwerk, zoo onberispelijk en zoo dun (de mantel toch is slechts enkele millimeter dik) te vervaardigen.

Waar komt echter de trom van daan? Hoe heeft ze eertijds gehangen? En waartoe heeft ze gediend?

Dit zijn drie vragen die bij beschouwing van zoo'n geheimzinnig voorwerp onwillekeurig oprijzen. Ook alle vorige schrijvers over keteltrommen hebben zich natuurlijk dusdanige vragen gesteld en getracht er een oplossing voor te vinden; geheel beantwoord zijn ze echter nog geenszins.

"Die van Baly geloven vastelyk," aldus het bericht bij RumpHius, afgedrukt in 1705 , "dat het een wiel van den Maans wagen zy, eertyds zoo helder schynende, dat het de nacht verlichte, doch als zeker Fielt op een tyd daar teegen aanpiste, op dit licht gestoort zynde, omdat het hem in zyn nachtelyke dieveryen belette, zoo is het van die tyd af verroest en donker geworden: Evenwel heeft nooit de Koning van Baly het hert gehad dat stuk van zijn plaats te brengen, of iets daar van af te kappen; maar heeft 't zelve 7• Volgr. VII. 
aldus ter gedagtenis laten leggen". Dit is de oplossing die de Baliërs dus hadden gevonden op de eerste der vragen. Een afdoend antwoord, dat niet zooals dit "uit de lucht is gegrepen," vermag ik echter op die eerste vraag niet te geven.

Voor het tweede vraagstuk heeft HeGER de volgende oplossing gegeven. "Das Vorhandensein von mindestens vier solchen Henkeln bei allen Trommeln, sowie die heute noch in Hinterindien übliche Art des Befestigens derselben in einem Holzgestelle (s. Taf. XVIII) zeigt uns deutlich, dass diese Trommeln immer aufgehängt gebraucht worden sein müssen" (op. cit. p. 139, $1^{\mathrm{e}}$ kol.) Met dat "aufgehängt" bedoelt hij in dit verband natuurlijk: zooals plaat XVIII in zijn werk dat te zien geeft; namelijk tusschen 4 houten pilaartjes, die op een houten voet zijn aangebracht. "Dies war auch nothwendig, um die durch das Schlagen auf den Stern der Platte hervorgebrachten Schwingungen des ganzen Trommelkörpers möglichst wenig zu stören" voegt hij er nog aan toe.

Voor deze meening pleit ook een van de oude Chineesche berichten, door Prof. DE GRoot medegedeeld. ${ }^{1}$ "In de Yuen-foeng periode $(1078-86)$ vond een landbouwer van Tsjwang, in Yoengkhing gelegen, die aan het ploegen was, een bronzen trom met ronde open zijde en vierkante hengsels. Er onder stond een vierkant voetstuk, evenals de trom zelf alom versierd met de teekens "wolken en donder" in (antiek) twan-schrift." Hier is dus sprake van een vierkant voetstuk dat buiten twijfel bij de trom behoorde; vierkant, daar deze vorm, door de vier hoeken, de beste gelegenheid aanbood voor het plaatsen van 4 pilaartjes, waartusschen de trom dan kon worden opgehangen, zoodanig, dat het bovenvlak horizontaal kwam te liggen.

Bij alle tot nu toe bekende exemplaren zoude men inderdaad, wanneer ze aldus waren opgehangen, er naast staande, gemakkelijk op de middenster kunnen slaan; bij de Pedjeng'sche echter, wegens haar meer dan manshoogte, zou dit niet mogelijk zijn. Deze moet dus eertijds in een soort toren gehangen hebben, met om de 4 palen, die haar ondersteunden, een platform (of met tenminste aan één zijde een platform) en met een trap er heen, om het mogelijk te maken de ster, de aangewezen plaats toch om op te slaan, te bereiken. Dat de trom wel degelijk gehangen heeft met het bovenvlak horizontaal, dus in den stand waarin ze op $\mathrm{Plaat}$ II is afgebeeld,

${ }^{1}$ In diens reeds genoemd opstel, blz. 344. 
daarvoor zijn de hoofden, die alsdan in de natuurlijke houding staan, een sterk bewijs.

En nu de derde vraag: "Waartoe heeft de trom van Pedjeng eertijds gediend?"

Drs. Meyer \& Foy en Prof. de Groot hebben het vermoeden geuit - naar 't mij lijkt een zeer aannemelijk vermoeden - dat de trommen waarop zich kikkers bevinden, gediend zouden hebben tot het afsmeeken aan den hemel van regen; tot regenroepers of regenwekkers dus. Maar er zijn ook trommen, als de Pedjeng'sche, waarop die water-kwakers niet annwezig zijn; die trommen dus zijn voorzeker geen regenroepers.

In de oude Chineesche berichten nu, reeds in die uit de zevende eeuw, zijn verschillende bewijzen te vinden, dat er ook trommen tot andere doeleinden werden gebruikt, o. a. tot het bijeenroepen van de strijdbare mannen in tijden van oorlog; deze trommen, krïgstrommen dus, zullen ander ornament hebben vertoond dan de regenroepers en zeker geen kikkers.

In de elfde en twaalfde eeuw moeten er zelfs zeer vele van die krijgstrommen zijn geweest, zooals uit het volgende blijkt.

"Het "Boek der Muziek", ," (aldus schrijft Prof. DE Groot, blz. 34.6) "een lijvig werk van de hand van Tsjhen Yang, een hoog ambtenaar in de elfde en de twaalfde eeuw, deelt namelijk mede: "In de Mān'sche landen komen bronzen trommen veelvuldig voor. "Het grootst in aantal zijn die, welke in de met figuren versierde "kringen geharnaste krijgers vertoonen. Zij zijn inwendig hol en "zonder bodem. Hun naam luidt: bronzen trommen." Bronzen oorlogstrommen dus!

$\mathrm{Nu}$ wil ik geenszins beweren dat alle trommen zonder kikkers, oorlogstrommen waren; de Chineesche berichten toch spreken duidelijk nog van andere, godsdienstige, doeleinden waartoe trommen gebruikt werden. Bv. "In het eerste jaar der periode Yoeng-hi (984)," dus melden ons de Historiën der Soeng-dynastie, "werd uit Zuidelijk Khiën (het zuiden der provincie Kwei-tsjioe) gerapporteerd, dat de barbaarsche Lao's in Khi-thoeng (het hedendaagsche Tsjen-yuen, een departement in diezelfde provincie) bij ziektegevallen op bronzen trommen en zandkleurige gongs plachten te slaan, en op die wijze offerdienst ter eere van zielen en geesten verrichtten." (De Groot, p. 342).

Ook bij dansen werden zij gebruikt: "Sobald die Nephritmuschel geblasen wird, erheben sich die Haarschöpfigen; sobald die Bronze- 
trommel angeschlagen wird, fangen die Tätowierten an zu hüpfen.” ${ }^{1}$

Maar de trom van Pedjeng meen ik wel degelijk een oorlogstrom te mogen noemen. Het eenige ornament toch, dat, wanneer de trom is opgehangen, de aandacht zal trekken, blijft het hoofden-ornament; die vier paar koppen, - die met hun groote oogeu uitzien naar de vier hemelstreken, als om uit heel den omtrek de strijdbare mannen op te sporen en met het machtige geluid van de trom op te roepen tot den krijg.

Twee zeer merkwaardige keteltrommen, zoo niet de merkwaardigste trommen die bekend zijn, blijken dus zich in onze Oost te bevinden: de zeer belangrijke, en tot voor kort de grootste trom op Saleier, waarvan de heer VAN HoËVELL de uitvoerigste mededeelingen en afbeeldingen gaf in het Internationale Archiv; en de trom te Pedjeng die $i k$ in deze bladzijden getracht heb, zoo nauwkeurig mogelijk te beschrijven en af te beelden.

Aan boord van "De Zwerver", Jan. 1908.

I Fr. Hrrth. Chinesische Ansichten über Bronzetrommeln. Mitteilungen des Seminars für orientalische Sprachen. Jahrgang VII (1904), Erste Abteilung, p. 210. 


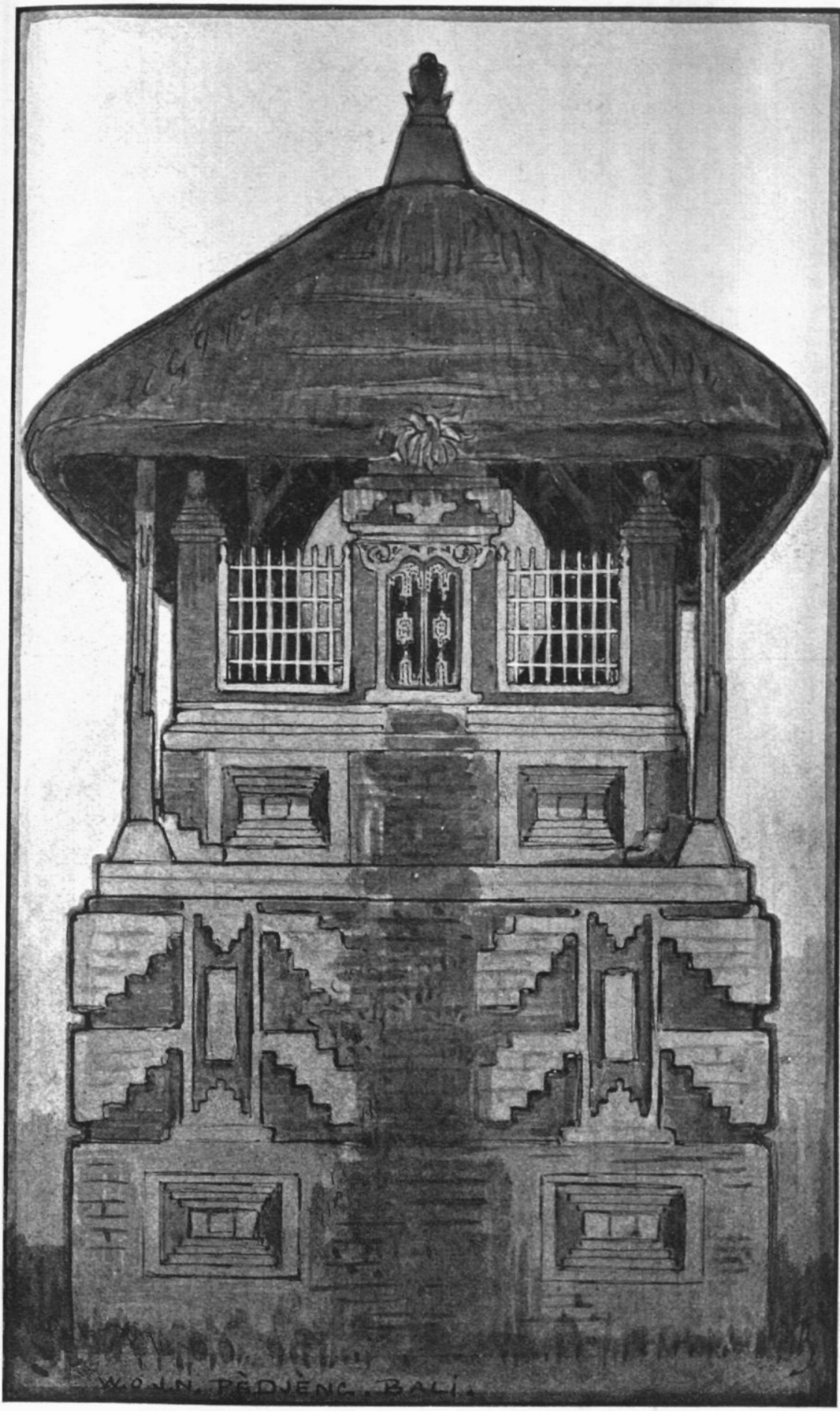

sict tempeltie met de ,maan van şafi”; Pesjeng, Gianjar. 


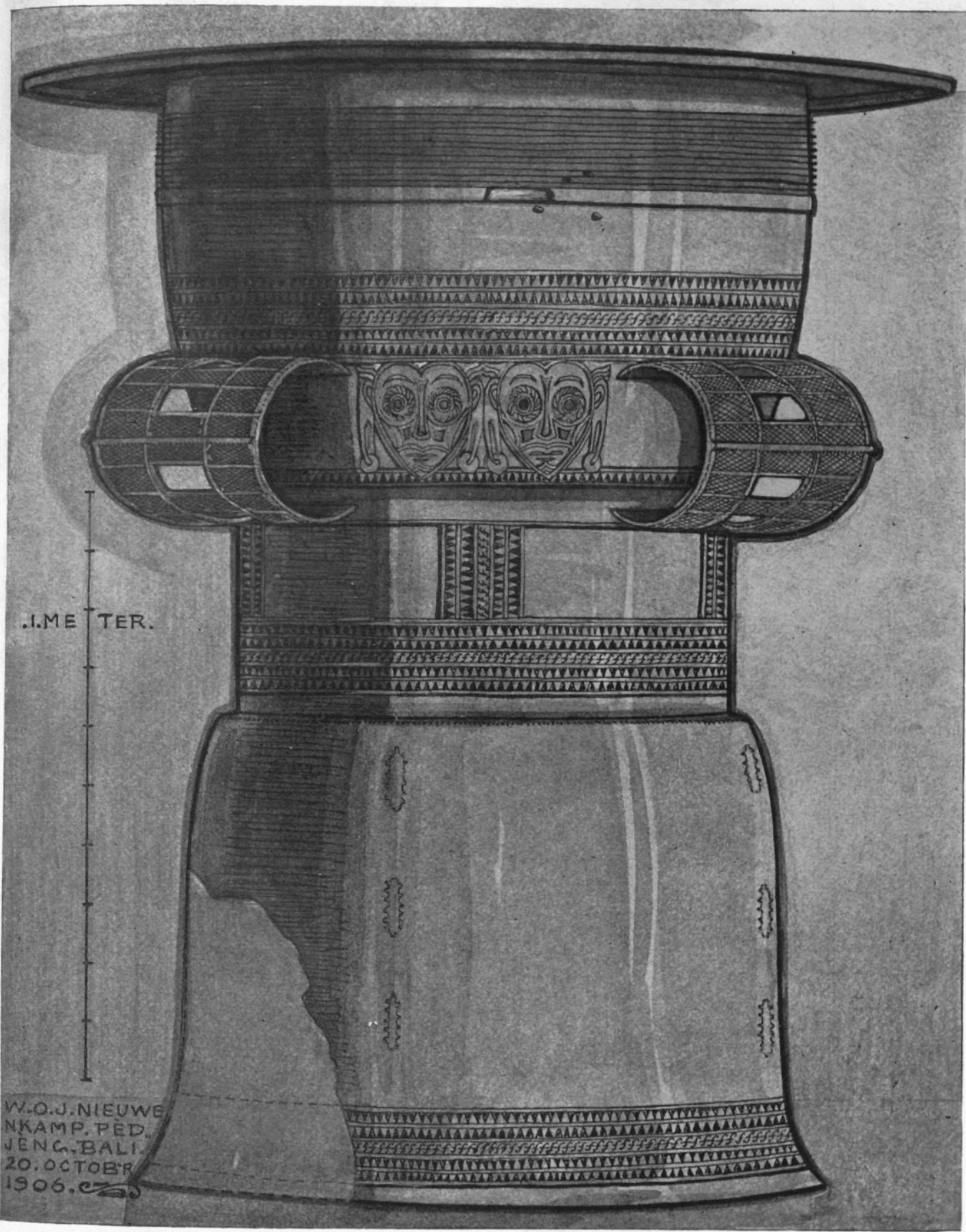

De ,from met de hoofben”; Peojeng, Daati. 
Plaat III.

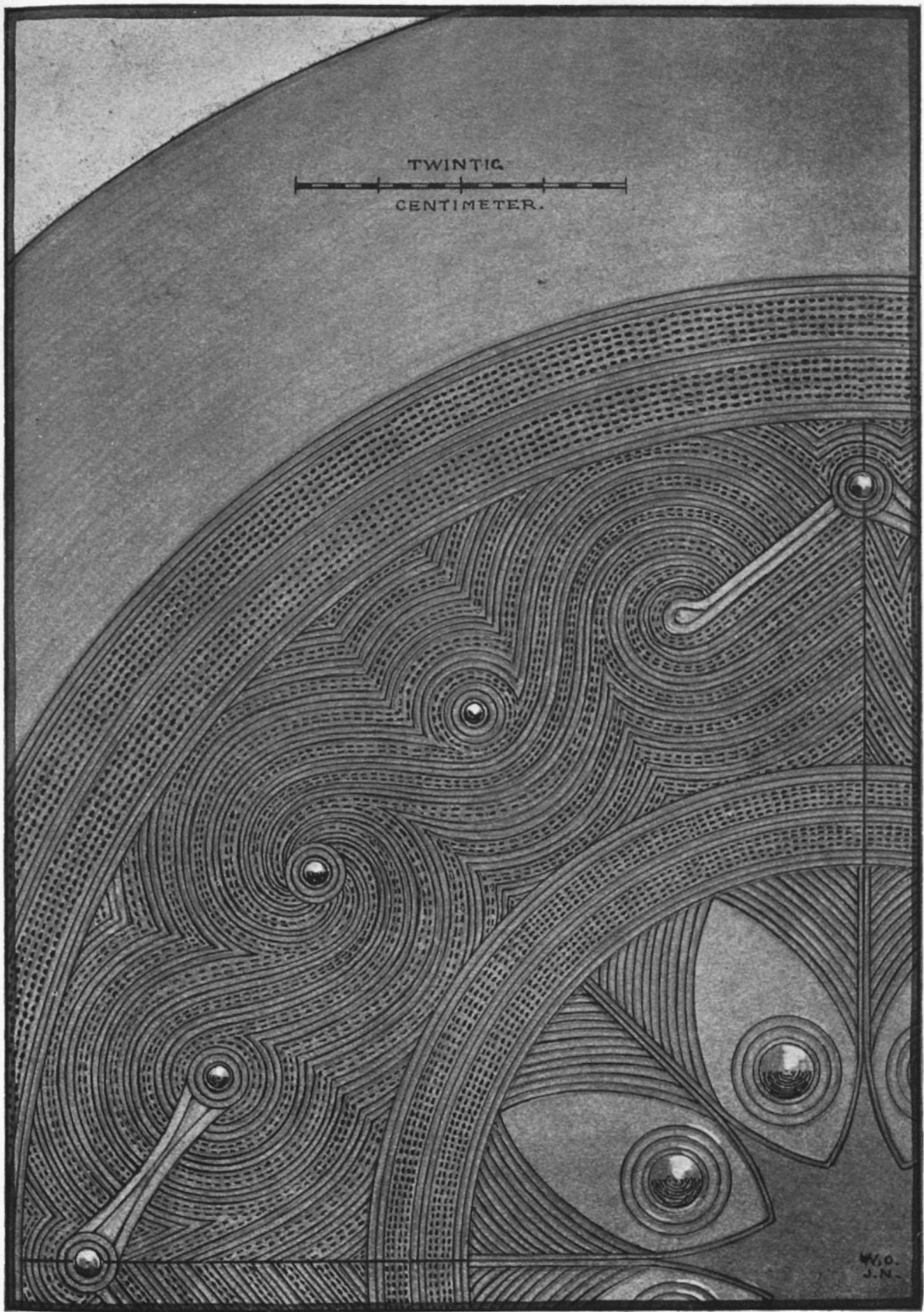

Drnament op het bovenwlak van se trom te Pesjeng. 
Plaat IV.

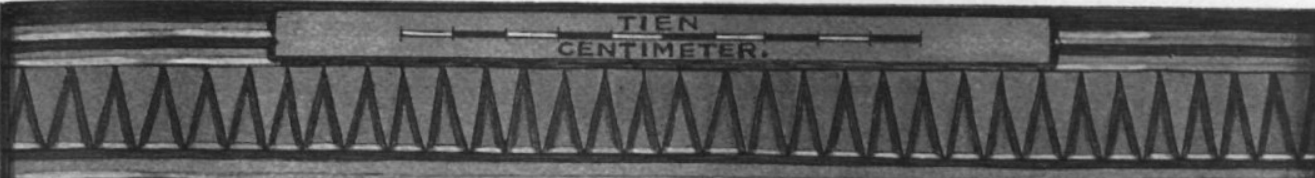

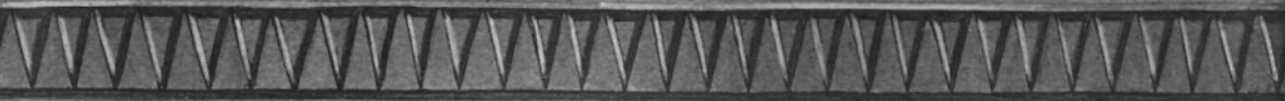

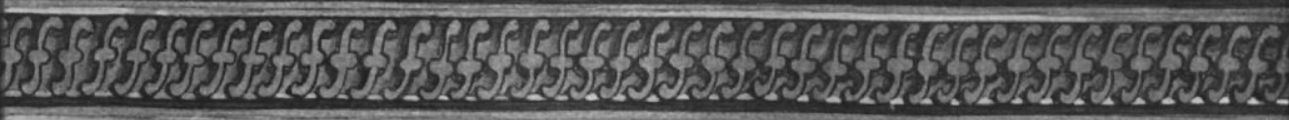

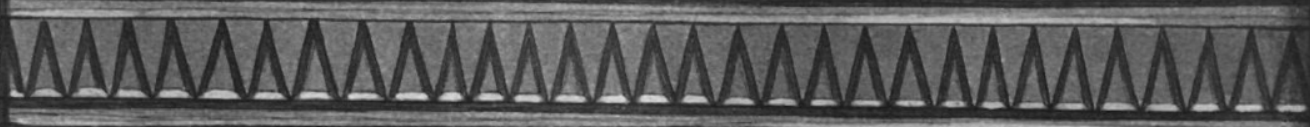

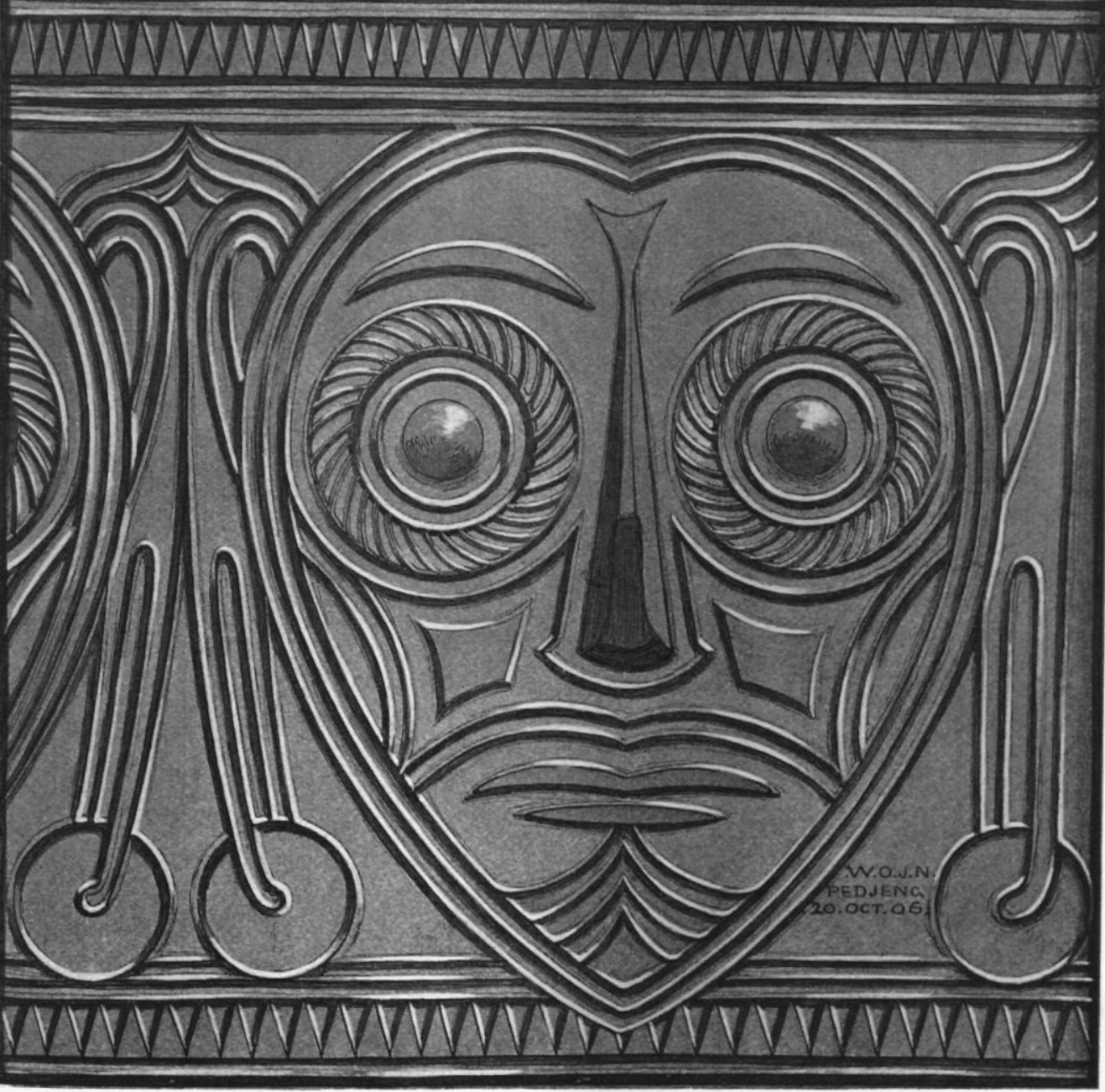

Eén van de hoofden. 
Plaat V.

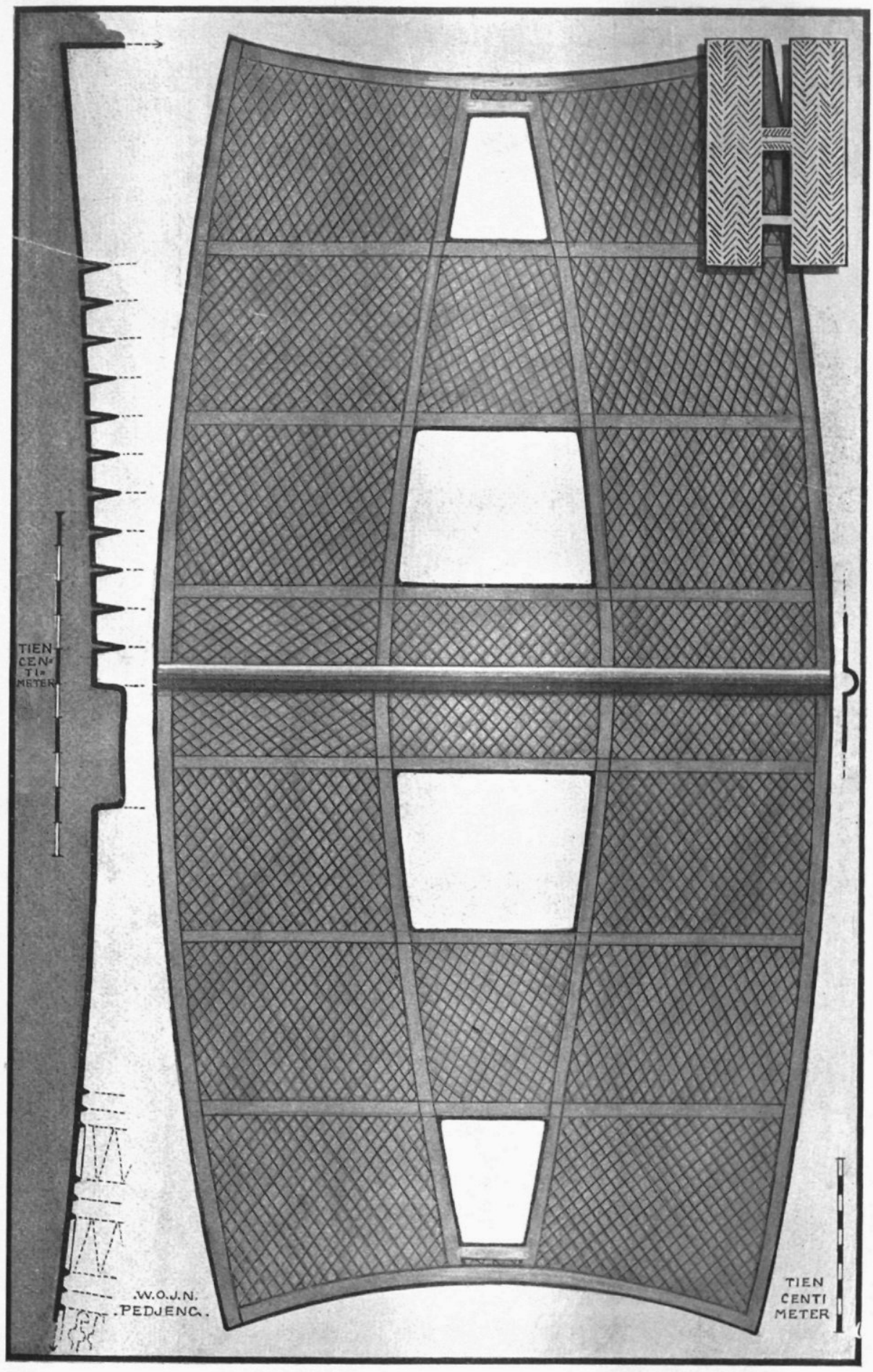

(Sinks): profiel van een stuk van bet bovengebeelte der from. (In 't midoen): een oor of bengsel' (plat uitgeslagen); en in ben recbter-bovenboek bet grootste bij siger afgebeelde oor. 


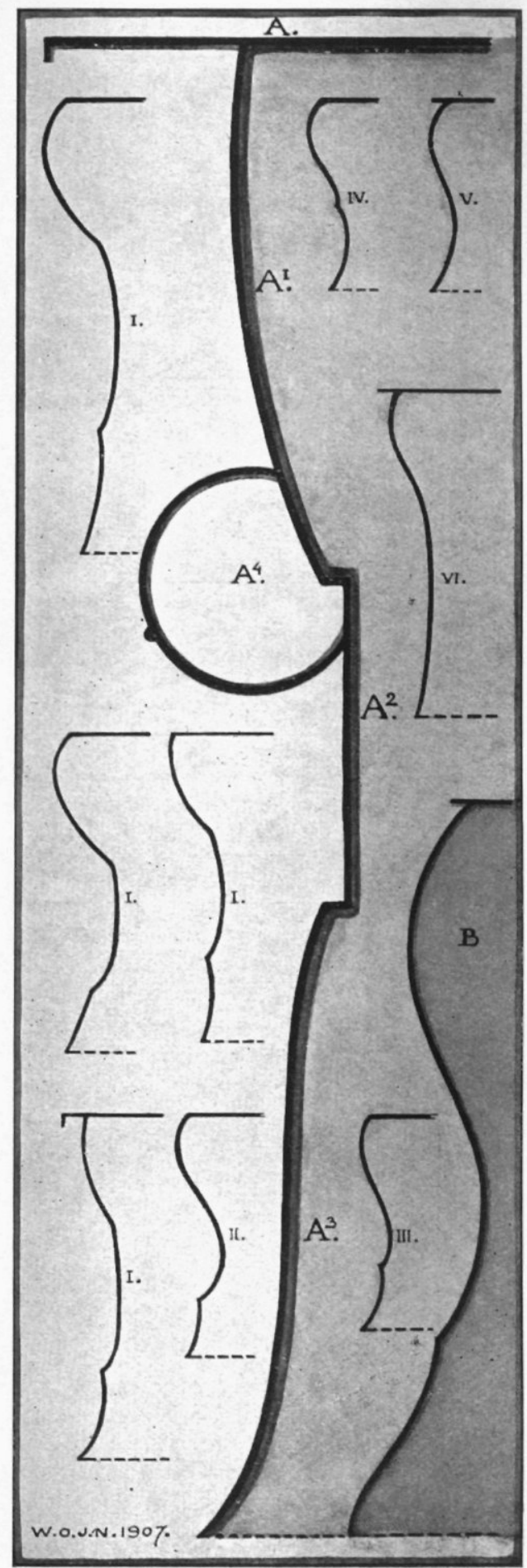

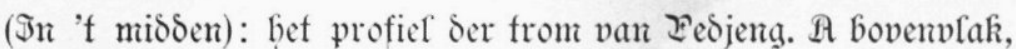

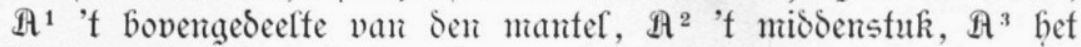
kTokvormig ondergebeelte, $A^{+}$een ber ooren.

33: profiel der from van saleier.

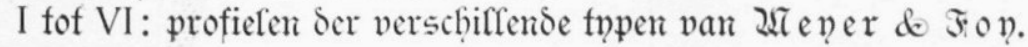

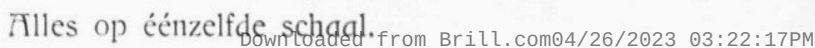

